\title{
Studies on the Lipid Profiles of Wistar Rat Models Treated with Aqueous and Methanolic Leaf Extracts of Alchornea Cordifolia and Thaumatococcus Daniellii
}

\author{
Osuocha, K. U. ${ }^{1}$, Ewa, O. ${ }^{1}$, Nweke, E. O. ${ }^{2}$, Ejiofor, D. C. ${ }^{3} \&$ Njoku, P. ${ }^{1}$ \\ ${ }^{1}$ Department of Medical Biochemistry, Gregory University Uturu Nigeria, Nigeria \\ ${ }^{2}$ Department of Human Anatomy, Chukwuemeka Odumegwu Ojukwu University Uli, Nigeria \\ ${ }^{3}$ Department of Human Physiology, Imo State University Owerri Nigeria, Nigeria \\ Correspondence: Ewa Ogbonnaya, Department of Medical Biochemistry, Gregory University Uturu, Nigeria.
}

Received: January 9, 2019; Accepted: January 22, 2019; Published: January 29, 2019

\begin{abstract}
This study aims at establishing the effect of $T$. daniellii and A. cordifolia leaf extracts on the lipid profile of experimental rat models. A total of twenty five (25) adult male wistar rats were used for the study. The rats were divided into five groups of five rats each. Group I (normal control) was administered with $2 \mathrm{ml} / \mathrm{kg}$ distilled water p.o. Group II was administered with $200 \mathrm{mg} / \mathrm{kg}$ aqueous leaf extract of $T$. daniellii p.o. Group III was administered with $200 \mathrm{mg} / \mathrm{kg}$ methanolic leaf extract of $T$. daniellii p.o. Group IV and V were administered with $200 \mathrm{mg} / \mathrm{kg}$ aqueous and methanolic leaf extracts of $A$. cordifolia respectively. Administration of extracts lasted for 14 days after which animals were sacrificed and serum developed from blood samples was collected and used for analysis to evaluate the lipid profiles of experimental models using standard methods. Results obtained from the study show that the highest level of Low Density Lippoprotein (LDL) $(31.21 \pm 0.04 \mathrm{mg} / \mathrm{dL})$ was recorded on Group II and was not significantly different from the control group $(33.20 \pm 0.10 \mathrm{mg} / \mathrm{dL})$. However, for High Density Lipoprotein (HDL), the highest level was recorded on Group IV $(48.14 \pm 0.08 \mathrm{mg} / \mathrm{dL})$. Similarly, this was not significantly different from the Control group $(51.80 \pm 0.10 \mathrm{mg} / \mathrm{dL})$. Group II presented the highest level of Triacylglyceride (TG) $(48.80 \pm 0.02 \mathrm{mg} / \mathrm{dL})$, which however, was considered not significantly different from the control group $(51.17 \pm 0.08 \mathrm{mg} / \mathrm{dL})$. For Total Cholesterol (TC), highest level $(64.64 \pm 0.49 \mathrm{mg} / \mathrm{dL})$ was recorded on Group II and value was not significantly different from that recorded on the normal control $(63.83 \pm 0.10 \mathrm{mg} / \mathrm{dL})$. In conclusion, it can be deduced from this study that extracts of $T$. daniellii and A. cordifolia lacks the potential to alter the lipid profile of patients depending on them for one medicinal use or the other and may thus be considered potential candidates for drug development.
\end{abstract}

Keywords: Alchornea cordifolia, Thaumatococcus daniellii, drug, lipid

\section{Introduction}

The plant Alchornea cordifolia is a small shrubby tree which originates from Senegal, East to Kenya,Tanzania and South throughout Central Africa to Angola. The various parts of the plant are used in the African traditional medicine practices. A. cordifolia is richly endowed with diverse phytochemicals. This is evident by the fact that the leaves, roots and stem bark have terpenoids, steroid, glycosides, flavonoids, tannins, saponins, imidazopyrimidine alkaloids, alchorneine, alchornidine and several guanidine alkaloids. The leaf is a rich source of hydroxybenzoic acids, gallic acid, ethyl ester, gentisic acid, anthranilic acid (vitamin L1) protocatechuic acid, as well as also ellagic acid (Agbor et al., 2004).

The globally prominent plant Thaumatococcus daniellii Benn (Benth.) belongs to the family Maranthaceae (Makinde and Taiwo, 2004). It predominates in Southern Ghana, Cote d'Ivoire as well as Nigeria (Yeboah et al., 2003). It has long, slender stalks that can grow up to two or three meters high, each bearing a single tough, ovoid shaped leaf of varying sizes depending on the plant's age and habitat (Makinde \& Taiwo, 2004). The leaf has been found to contain high amount of phytochemicals such as flavonoids, alkaloids, saponin, tannin anthraquinones and steroids. Traditionally, the leaf sap of this plant is used in the treatment of venoms, stings and bites, while the leaf and root sap have been used successfully as sedatives as well as in the treatment of mental illness (Onwueme et al., 1979). 
Lipids are chemically heterogeneous group of compounds which are insoluble or sparingly soluble in water but however are soluble in non-polar solvent (Dhaliya et al., 2013). The biological relevance of lipids cannot be overemphasized as they function in varying capacities such as structural components of all membrane, medium for storage and transportation of metabolic fuel, carriers of fat soluble vitamins A, D, E and K etc (Newton, 2001). Lipids are classified as Total Cholesterol (TC), Triglycerides (TG), Low Density Lipoprotein (LDL), High Density Lipoprotein (HDL) and Very Low Density Lipoprotein (VLDL) cholesterol which generally play essential role in the movement of cholesterol around the body (Ginsberg, 2001).

The human body is a complex machinery in which the homeostasis of various organs must be consistently maintained as any undesirable change will distort the balance and consequently results to diseased condition. It is pertinent to note that several medications and medication classes have been reported to affect the lipid profile of an exposed individual (Megan, 2018). Therefore, it is imperative to experimentally evaluate the effects of $T$. daniellii and $A$. cordifolia on the lipid profiles of rat model to ascertain their suitability as candidates for drug development.

\section{Materials and Methods}

\subsection{Collection and Preliminary Processing of Plant Material}

Leaves of T. daniellii and A. cordifolia were harvested from a farm located in Achara Uturu Isiukwuato Local Government Area of Abia State, Nigeria after which they identified at the herbarium unit of the Department of Forestry, Micheal Okpara University of Agriculture Umudike, Abia State Nigeria. The leaves separately washed thoroughly with clean water before being dried at room temperature. Dry leaves were ground to powder, sieved with a suitable wire mesh to obtain a fine powder which was subsequently stored in an air tight container.

\subsection{Extraction of Plant Materials}

One hundred gram $(100 \mathrm{~g})$ each of the powdered sample materials was soaked separately in $1000 \mathrm{ml}$ of methanol and water and macerated at room temperature for a period of $72 \mathrm{~h}$. The mixture was agitated thrice daily. The mixture was strained and the damp solid material, pressed, and the combined liquids were filtered using cheesecloth and Whatman No. 1 filter paper. The filtrate was extracted using soxhlet apparatus for 5-6h and concentrated under pressure to dryness in rotary evaporator at $25-30^{\circ} \mathrm{C}$ (Phrompittayarat et al., 2008). The extracts were placed in the refrigerator and maintained at $5-10^{\circ} \mathrm{C}$.

\subsection{Animal}

Twenty five (25) adult male albino rats (116-122g) were obtained from the Animal House of the Department of Pharmacology, University of Nigeria Nsukka and subsequently housed in plastic cages in a well ventilated room with a 12/12hr light/dark cycle and ambient temperature for three weeks to acclimatize.

\subsection{Median Lethal Dose 50\% Test (LD50)}

Acute toxicity test was separately conducted on $T$. daniellii and A. cordifolia leaf samples. Three groups of three rats each were orally administered with $10 \mathrm{mg}, 100 \mathrm{mg}$, and $1000 \mathrm{mg} / \mathrm{kg}$ of sample substance before being observed for $24 \mathrm{hrs}$. In the absence of mortality in any of the groups, another three groups of one rat each were administered with 1600,2900 and $5000 \mathrm{mg} / \mathrm{kg}$ of extract respectively and the animals were observed for $48 \mathrm{hrs}$ (Lorke, 1983).

\subsection{Experimental Design}

Twenty five adult male wistar rats used for the study were grouped into five groups of five rats each and were subjected to treatment for 14 days as follows:

Group I (normal control) - $2 \mathrm{ml} / \mathrm{kg}$ distilled water (p.o)

Group II - 200mg/kg aqueous extract of T.d (p.o)

Group III - 200mg/kg methanolic extract of T.d (p.o)

Group IV $-200 \mathrm{mg} / \mathrm{kg}$ aqueous extract A.c (p.o)

GroupV - 200mg/kg methanolic extract A.c (p.o)

\subsection{Sample Collection and Determination of Lipid Profile}

At day 14 of treatment, animals were sacrificed and blood collected via cardiac artery into plain bottle and allowed to clot. Serum was harvested from the clotted blood after centrifugation at $1500 \mathrm{rpm}$. The lipid profile such as Total cholesterol (TC), Triglycerides (TG), high density lipoproteins (HDL) and low density lipoproteins were estimated by standard methods (Rifai and King, 1986). 


\section{Statistical Analysis}

Statistical analysis was carried out using IBM Statistical Package for the Social Sciences Statistical Package (SPSS)V 23.0. Data were expressed as means \pm SEM of three replicates

\section{Result}

Table 1. Lipid profiles of rats administered with aqueous and methanolic extracts of $T$. daniellii and A. cordifolia

\begin{tabular}{lllll}
\hline Groups & LDL $(\mathrm{mg} / \mathrm{dL})$ & $\mathrm{HDL}(\mathrm{mg} / \mathrm{dL})$ & $\mathrm{TG}(\mathrm{mg} / \mathrm{dL})$ & $\mathrm{TC}(\mathrm{mg} / \mathrm{dL})$ \\
\hline Group I(Normal control) & $33.20 \pm 0.10$ & $51.80 \pm 0.10$ & $51.17 \pm 0.08$ & $63.83 \pm 0.10$ \\
Group II (200mg/kg aq. T.d) & $31.21 \pm 0.04$ & $47.31 \pm 0.10$ & $48.80 \pm 0.02$ & $64.64 \pm 0.49$ \\
Group III (200mg/kg met. Td) & $30.15 \pm 0.04$ & $40.23 \pm 0.01$ & $47.40 \pm 023$ & $62.27 \pm 0.28$ \\
Group IV (200mg/kg aq.Ac) & $30.04 \pm 0.04$ & $48.14 \pm 0.08$ & $47.29 \pm 0.12$ & $61.92 \pm 0.06$ \\
Group V (200mg/kg met. Ac) & $30.12 \pm 0.05$ & $46.21 \pm 0.06$ & $46.09 \pm 0.12$ & $61.42 \pm 0.13$ \\
\hline
\end{tabular}

Values are expressed as mean \pm SEM from three determinations

\section{Discussion}

Lipids are organic compounds which are chemically heterogeneous and are insoluble or sparingly soluble in water but can dissolve in non-polar solvent (Dhaliya et al., 2013). Lipids function in varying capacities such as structural components of all membrane, medium for the storage and transportation of metabolic fuel, carriers of fat soluble vitamins A, D, E and K etc (Newton, 2001).

Table 1 shows the lipid profiles of rats administered with aqueous and methanolic leaf extracts of $T$. daniellii and $A$. cordifolia. Results obtained from the study indicate that group II administered with $200 \mathrm{mg} / \mathrm{kg}$ aqueous leaf extract of $T$. daniellii manifested the highest level of Low Density Lipoprotein (LDL) $(31.21 \pm 0.04 \mathrm{mg} / \mathrm{dL}$ ) among the treatment groups i.e. (groups II-V) though not significantly differently from the control $(33.20 \pm 0.10 \mathrm{mg} / \mathrm{dL})$. Group IV administered with $200 \mathrm{mg} / \mathrm{kg}$ aqueous leaf extract of $A$. cordifolia presented a higher level of High Density Lipoprotein (HDL) compared to other treated groups. It is important to note that the value recorded on the HDL level of Group IV is not significantly different from that of the control group (group I). Group II manifested the highest level of Triacylglyceride (TG) $(48.80 \pm 0.02 \mathrm{mg} / \mathrm{dL})$ but however, was considered not significantly different from the control group $(51.17 \pm 0.08 \mathrm{mg} / \mathrm{dL})$. For Total Cholesterol (TC), highest level $(64.64 \pm 0.49 \mathrm{mg} / \mathrm{dL})$ was recorded on Group II and value was also not significantly different from that indicated on the normal control $(63.83 \pm 0.10 \mathrm{mg} / \mathrm{dL})$. These results are consistent with the findings of Ama et al., (2015) and Shalom et al., 2018 which have shown the hypolipidemic potentials of ethanolic leaf extracts of $A$. cordifola and $T$. daniellii respectively.

\section{Conclusion}

In conclusion, this research has shown that extracts of $T$. daniellii and $A$. cordifolia leaves have no adverse effects to on the lipid profiles of experimental model, a virtue which has presented them as ideal candidates for drug development.

\section{References}

Agbor, G. A., Leopold, T., \& Jeanne, N. Y. (2004). The antidiarrhoeal activity of Alchornea cordifolia leaf extract. Phytotherapy Research, 18(11), 873-76. https://doi.org/10.1002/ptr.1446

Ama, K. T., Kwesi, P. T., Fred, A., Dominic, A. E., Kobena, A. T., Elvis, O., Ameyaw1, J. N., Boampong, M. E., \& Bioh, S. A. (2018). The Ethanolic Leaf Extract of Alchornea cordifolia (Schum. \&Thonn.) Muell. Arg Inhibits the Development of Dyslipidaemia and Hyperglycaemia in Dexamethasone-Induced Diabetic Rats. Journal of Applied Pharmaceutical Science, 5(9), 052-055.

Dhaliya, S. A., Surya, A. S., Dawn, V. T., Betty, C., Arun, K., \& Sunil, C. (2013). A Review of Hyperlipidemia and Medicinal Plants. Int.J.A.PS.BMS, 2(4), 219-237.

Ginsberg, H. N., \& Goldberg, I. J. (2001). Disorders of lipoprotein metabolism. In: Harrison's Principles of Internal Medicine. 15th Ed. New York: McGraw Hill, 2245-2256.

Lorke, D. (1983). A new approach to practical acute toxicity testing. Archives of Toxicology, 54(4), 275-287. https://doi.org/10.1007/BF01234480

Makinde, S. C. O., \& Taiwo, C. K. (2004). In situ population evaluation of Thaumatococcus danielli 
(Benth). ASSET International Journal, 1(3), 75-80.

Megan Herink, Pharm. Medication Induced Changes in Lipid and Lipoproteins.

Newton, I.S. (2001). "Long-Chain Fatty Acids in Health and Nutrition," In: F. Shahidi and J. W. Finley, Eds, Omega-3 Fatty Acids: Chemistry, Nutrition, and Health Effects, American Chemical Society, Washington DC, pp. 14-27. https://doi.org/10.1021/bk-2001-0788.ch002

Onwueme, I. C., Onochie, B. E., \& Sofowora, E. A. (1979). Cultivation of Thaumatococcus daniellii the sweetener. World Crops, 3, 106-111

Rifai, N., \& King, M. E. (1986). Immunoturbidimetric assays of apolipoproteins A, A-1, A-2 and B in serum. Clin Chem, 32(1986), 957-958.

Shalom, N. C., Franklyn, N. I, Boluwatife, T. M., Babajide, O. T., \& Opeyemi C. E. (2018). In vivo antioxidant, hypolipidemic and hepatoprotective potential of Thaumatococcus Daniellii (Benn.) Benth leaves Elsevier, 20(2018), 364-370.

Virchow, R. P., \& Thrombose, I. G. (1956) In Gesammelte Abhandlungen zur Wissenschaftlichen Medicin. Frankfurt-am-Main, Meidinger Sohn \& Company, S458-564.

Yeboah, S. O., Hilger, T. H., \& Kroschel, J. (2003). Thaumatococcus danielli (Benth): A natural sweetener from the rain forestzone in West Africa with potential income generation in small scale farming. J. Applied Sci., 6, 854-859.

\section{Copyrights}

Copyright for this article is retained by the author(s), with first publication rights granted to the journal.

This is an open-access article distributed under the terms and conditions of the Creative Commons Attribution license (http://creativecommons.org/licenses/by/4.0/). 